\title{
GENOTYPIC DIFFERENCES IN GROWTH AND IONS ACCUMULATION IN SOYBEAN UNDER NaCI SALINITY AND WATER STRESS CONDITIONS
}

\author{
M. S. A. Khan' ${ }^{1}$ M. A. Karim ${ }^{2}$ and M. M. Haque ${ }^{2}$ \\ ${ }^{1}$ Agronomy Division, BARI \\ ${ }^{2}$ Department of Agronomy, BSMRAU \\ Corresponding author: shawquatshahadat@yahoo.com
}

Key words: Salt and water stress, dry matter production, ions accumulation

\begin{abstract}
Salt and water stress tolerance of the seven soybean genotypes viz. BARI Soybean 6, BD 2329, BD 2342, AGS 95, BGH 02026, Galarsum and BD 2331 were evaluated for their performance at 0 and $100 \mathrm{mM} \mathrm{NaCl}$ under well watered \& water stress (watering with $70 \%$ depletion of available water at wilting) conditions at the Banghabandhu Sheikh Mujibur Rahman Agricultural University, Salna, Gazipur. The results indicated that all the growth parameters like plant height, shoot dry weight, root dry weight and dry matter distribution in different plant parts of the genotypes sharply decreased when the plants were exposed to water stress, salt stress and, combined salt and water stress conditions. Among the genotypes reduction in dry matter production was the least in Galarsum and BD 2331 in both the salt stress and, the combined salt and water stress conditions. These genotypes also accumulated lower amount of $\mathrm{Na}^{+}$and higher amount of $\mathrm{K}^{+}$in leaf tissues under salt stress and, combined salt and water stress environments as compared to others.
\end{abstract}

\section{Introduction}

Soybean is classified as a moderately salt-tolerant crop and the yield will be reduced when soil salinity exceeds $5 \mathrm{dS} \mathrm{m}^{-1}$ (Maas and Hoffman, 1977). High levels of salts in the soil can often cause serious limitations to crop production. Raptan et al. (2001) found that salinity decreased root, stem and leaf dry weights, and reduced plant height of mungbean plants. The adverse effect of salinity on plant is dependent on salt concentration in the substrate, duration of exposure to salinity and stages of plant growth (Blum, 1988; Maas and Poss, 1989; Gill, 1990). It is well known that salinity harms crop growth. Plants under high saline conditions cannot always absorb sufficient water for metabolic activities or maintain turgidity because of the low osmotic potential in the growth media. At the same time, plants absorb damaging amounts of $\mathrm{Na}$ and $\mathrm{Cl}$ (Blum, 1988; Greenway and Munns, 1980; Karim et al., 1992).

$\mathrm{Na}^{+}$is the primary cause of ion specific damage, resulting due to a range of disorders in enzyme activation and protein synthesis (Tester and Davenport, 2003). Therefore, exclusion of $\mathrm{Na}^{+}$at root level and maintenance of high $\mathrm{K}^{+}$at shoot level are vital for the plants to grow under saline conditions (Munns et al., 2000; Tester and Davenport, 2003).

It is very common in the arid and semi-arid regions that when the crop growth season progresses, the precipitation decreases, and temperature and evapo-transpiration increase, resulting in rising salt concentration in the soil solution (Abdulrahman and Williams, 1981). Thus, salt and water stress prevails at the same time in the dry seasons, which very often add extra harm on plant growth (Karim et al., 1993). Normally, salinity stress produces high osmotic potential in the soil solution (Hayward and Spurr, 1943), whereas water stress impairs soil moisture transmission due to matric potential (Gingrich and Russell, 1957). However, the adverse effects of both salt and water stress are primarily due to the restriction of water uptake by the roots (Karim et al., 1993). The response of soybean to salinity stress depends both on genotypes and environmental conditions (Ghassemi-Golezani et al., 2009). 
Khan et al.

In the coastal area of Bangladesh, soil salinity increases during dry period (March - May) due to lack of rainfall. Thus, salinity and drought exist together during that particular period. It is well known that salinity exerts more deleterious effects on plant growth when drought prevails along with salinity. Therefore, this study was undertaken to analyze the growth and mineral ions accumulation pattern in some soybean genotypes.

\section{Materials and Methods}

The experiment was conducted in a plastic house of the Department of Agronomy at Banghabandhu Sheikh Mujibur Rahman Agricultural University (BSMRAU), Salna, Gazipur, Bangladesh. Seven genotypes (BARI Soybean 6, BD 2329, BD 2342, AGS 95, BGH 02026, Galarsum and BD 2331) of soybean including BARISoybean 6 were used for testing their salt and water stress tolerance. Selected genotypes were denoted as moderately salt tolerant (Khan, 2013). Seeds were washed several times in the tap water for surface cleaning then sown in the soil medium on January 13, 2011 in plastic pots having 30 $\mathrm{cm}$ in height and $24 \mathrm{~cm}$ inner diameter. Each pot contained $12 \mathrm{~kg}$ air dried sandy loam soil. Chemical fertilizers of $0.30 \mathrm{~g}$ urea, $0.90 \mathrm{~g}$ TSP, $0.60 \mathrm{~g}$ MOP and $0.60 \mathrm{~g}$ Gypsum per pot were also incorporated into the soil before sowing. The pots were watered daily for easy germination. After the emergence and establishment, three uniform healthy seedlings per pot were allowed to grow for three weeks (21 DAE) in equal environment. After three weeks of emergence, all the genotypes were divided into 6 groups. The treatment groups were; Control $\left(\mathrm{T}_{1}\right)$, water shortage (irrigated with $70 \%$ depletion of available soil water when wilting sign developed) from $21 \mathrm{DAE}\left(\mathrm{T}_{2}\right), 50 \mathrm{mM} \mathrm{NaCl}$ irrigated from $21 \mathrm{DAE}\left(\mathrm{T}_{3}\right), 50 \mathrm{mM}$ $\mathrm{NaCl}$ irrigated from $21 \mathrm{DAE}+$ water shortage from $35 \mathrm{DAE}\left(\mathrm{T}_{4}\right), 100 \mathrm{mM} \mathrm{NaCl}$ irrigated from $21 \mathrm{DAE}$ DAE $\left(T_{5}\right)$ and $100 \mathrm{mM} \mathrm{NaCl}+$ water shortage from $35 \mathrm{DAE}\left(\mathrm{T}_{6}\right)$. The control groups of plants were irrigated with tap water only. The experiment was arranged in two factors Completely Randomized Design (CRD) with 8 replications. Plant samples were collected in 42 DAE and different plant parts were separated and then oven dried at $70{ }^{\circ} \mathrm{C}$ for 4 days to measure the dry weight. Dried leaves were finely ground and the samples were dry-ashed at $500{ }^{\circ} \mathrm{C}$ for 8 hours and then digested with concentrated hydrochloric acid. Na and K concentrations were determined by a Flame Spectrophotometer. Data were analyzed by MSTAT-C program and the treatment means were compared by using Least Significant Difference (LSD).

\section{Results and Discussion}

\section{Plant height}

Plant height of soybean genotypes significantly decreased under water stress, salt stress and their combination (Fig. 1). Under only water stress condition, significantly the tallest plant recorded in BARI Soybean 6 and the shortest in BD 2331 genotype. Plant height was affected more in combined salt and water stress conditions than only in salt stress conditions in both the salinity levels (50 and $100 \mathrm{mM}$ $\mathrm{NaCl})$, though the reduction was higher at higher salinity levels. At higher salinity (100 $\mathrm{mM} \mathrm{NaCl})$, the tallest plant was recorded in AGS $95(26.13 \mathrm{~cm})$ followed by BD $2342(25.63 \mathrm{~cm})$ and the shortest in Galarsum $(22.47 \mathrm{~cm})$. At higher salinity $(100 \mathrm{mM} \mathrm{NaCl})$ combined with water stress condition, the tallest plant recorded in BD $2342(25.23 \mathrm{~cm})$ followed by BGH02026 $(25.13 \mathrm{~cm})$, while the shortest in BD 2329 $(20.10 \mathrm{~cm})$. The reduction of plant height was also more in higher salinity both in only salt stress and, combined salt and water stress conditions (Fig. 2). At higher salinity, the maximum relative plant height was recorded in BD 2331 (97.70\%) followed by AGS 95 (95.82 \%) and the lowest in BD 2329 (75.95 \%). But at higher salinity combined with water stress condition, the highest relative plant height recorded in AGS 95 (87.28 \%) followed by Galarsum (86.84 \%) and the lowest relative plant height in BD 2329 $(67.75 \%)$. Salt stress and water deficit significantly affected the plant height of soybean which is in agreement with Ozturk et al. (2004); Sari and Ceylan (2002). Osmotic potential of soil decreased due to salt water, and matric potential decreased due to water shortage in soil, which made interruption in water 
Genotypic Differences in Soybean Under NACL Salinity and Water Stress

uptake by the plant resulting in reduction of shoot growth, is commonly expressed by stunted shoot growth. Genotypic difference in the reduction of plant height due to salinity were also reported earlier by Aziz et al. (2005); Sultana et al. (2009) and Padder et al. (2012) in mungbean, Mannan et al. (2012) in soybean.

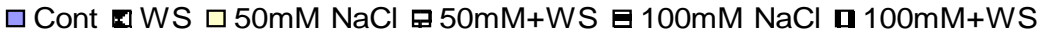

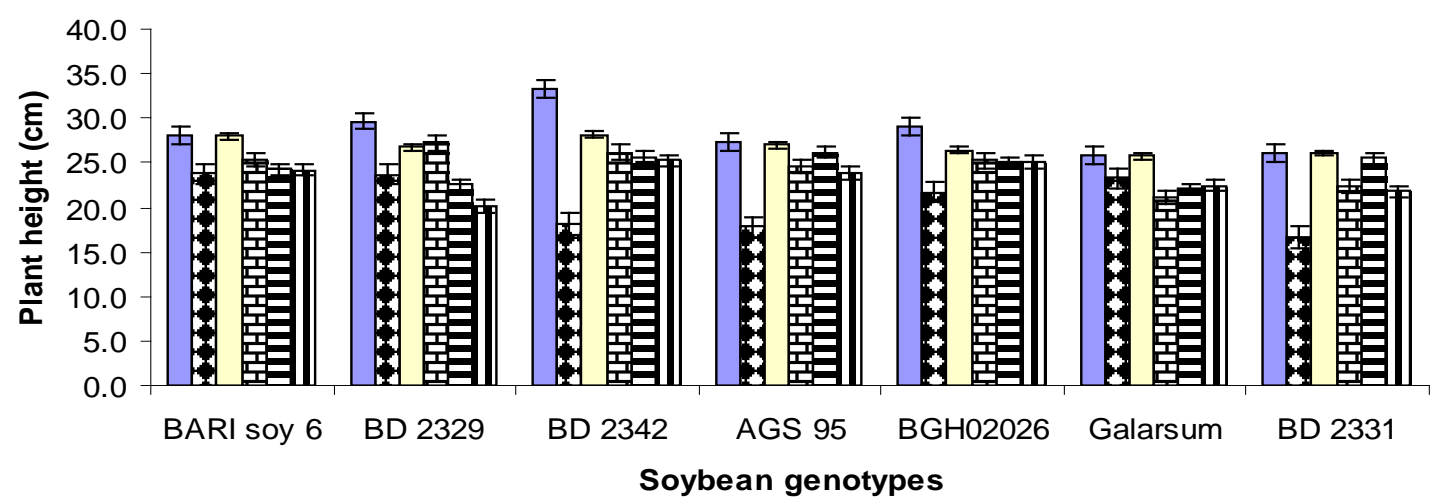

Here, Cont $=$ Control, $\mathrm{WS}=$ Water stress, $\mathrm{mM}=\mathrm{NaCl}$ concentration.

Fig.1. Plant height of soybean genotypes as affected by salinity and water stress, and their combination at $42 \mathrm{DAE}$

$\square$ Cont $\mathbf{w S} \square 50 \mathrm{mM} \mathrm{NaCl} \square 50 \mathrm{mM}+\mathrm{WS} \square 100 \mathrm{mM} \mathrm{NaCl} \square 100 \mathrm{mM}+\mathrm{WS}$

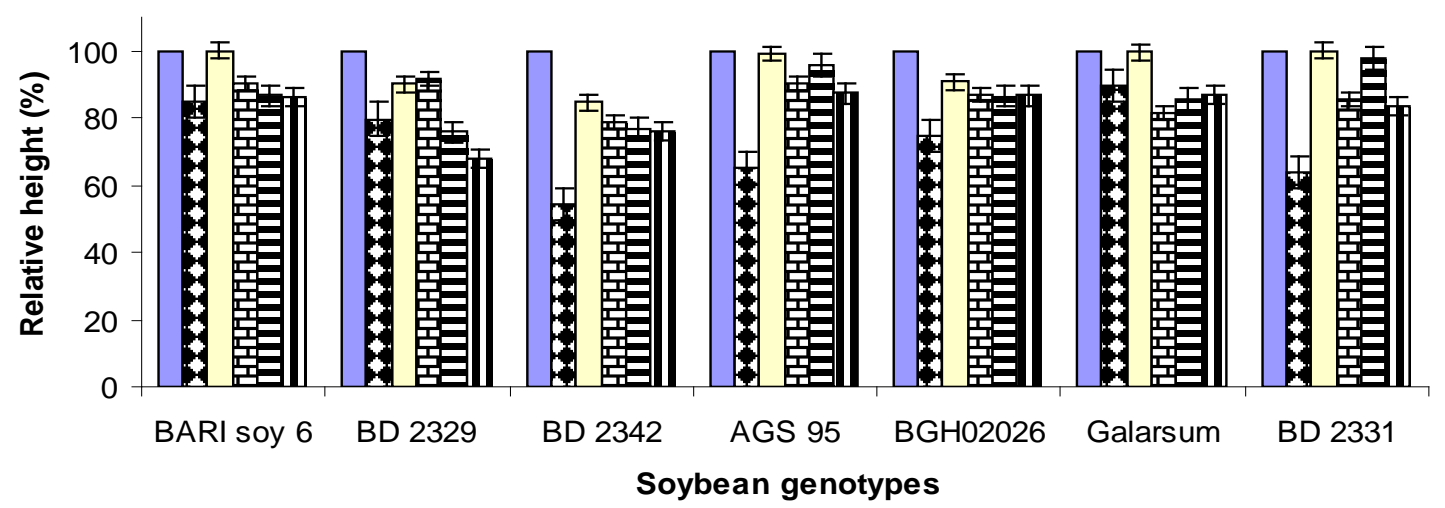

Here, Cont $=$ Control, WS $=$ Water stress, $\mathrm{mM}=\mathrm{NaCl}$ concentration .

Fig. 2. Relative plant height of soybean genotypes as affected by salinity and water stress, and their combination at $42 \mathrm{DAE}$

\section{Shoot dry weight}

Shoot dry weight of soybean genotypes sharply decreased when plants were exposed to water stress, salt stress and, combined salt and water stress (Fig. 3). Under only water stress conditions, BD 2342 produced the highest shoot dry weight (1.94 g) followed by BARI Soybean 6 (1.87 g), and the least recorded in BD 2331 (1.03 g). Shoot dry weight was affected more in the combined salt and water stress conditions than only in the salt stress in both the salinity levels (50 and $100 \mathrm{mM} \mathrm{NaCl}$ ). But the reduction was higher in higher salinity levels. At higher salinity $(100 \mathrm{mM} \mathrm{NaCl})$, the highest shoot dry weight recorded in BD 2342 (1.89 g) followed by BARI Soybean 6 (1.75 g) and the lowest in BGH 02026 (1.18 g). At the higher salinity combined with water stress condition, the highest shoot dry weight recorded in by BARI Soybean 
Khan et al.

6 (1.64 g), which was followed by BD 2342 (1.63 g) and the lowest recorded in BGH 02026 (1.18 g). The relative shoot dry weight of soybean reduced in water stress, salt stress and, combined salt and water stress conditions (Fig. 4). Under only water stress condition, the highest relative shoot dry weight recorded in BARI Soybean 6 (77.5 \%) followed by Galarsum (76.7 \%) and the lowest in AGS 95 (39.7 $\%)$. The relative shoot dry weight was reduced more in the combined salt and water stress conditions than only salt stress in both the salinity levels. At higher salinity $(100 \mathrm{mM} \mathrm{NaCl})$, the highest relative shoot dry weight was recorded in Galarsum (79.9 \%) followed by BD 2331 (77.9 \%) and the lowest in BD 2329 (50.2\%). But at higher salinity combined with water stress condition, the highest relative shoot dry weight wasrecorded in Galarsum (68.4\%) followed by BARI Soybean 6 (68.0\%) and the lowest recorded in BD 2329 (44.1\%).

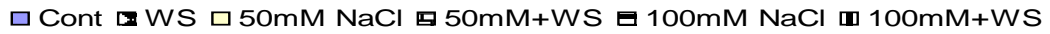

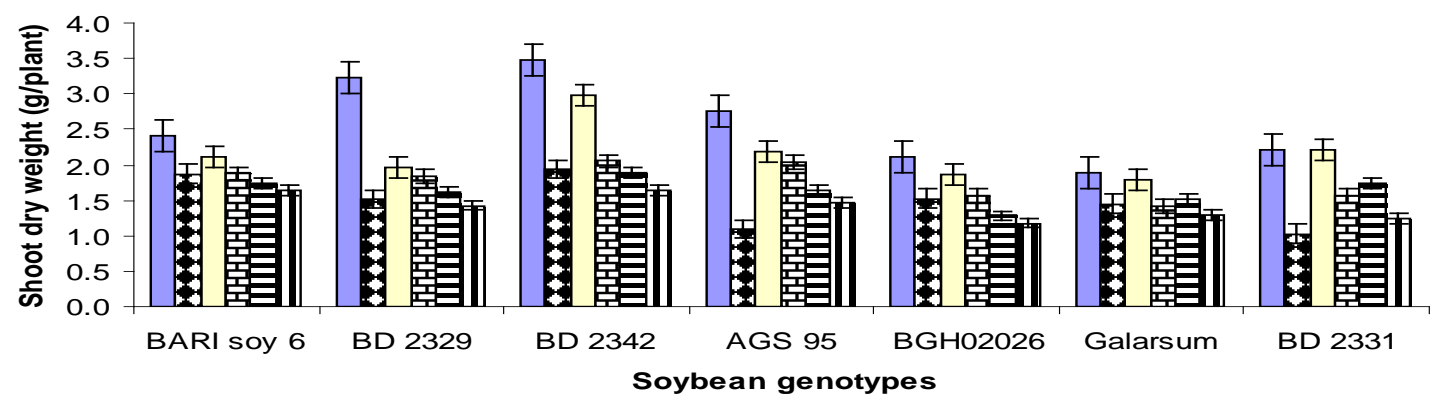

Here, Cont $=$ Control, WS $=$ Water stress, $\mathrm{mM}=\mathrm{NaCl}$ concentration .

Fig. 3. Shoot dry weight of soybean genotypes as affected by salinity and water stress, and their combination at $42 \mathrm{DAE}$

$\square$ Cont aWS $\square 50 \mathrm{mM} \mathrm{NaCl} \pm 50 \mathrm{mM}+\mathrm{WS}$ - $100 \mathrm{mM} \mathrm{NaCl}$ m 100mM+WS

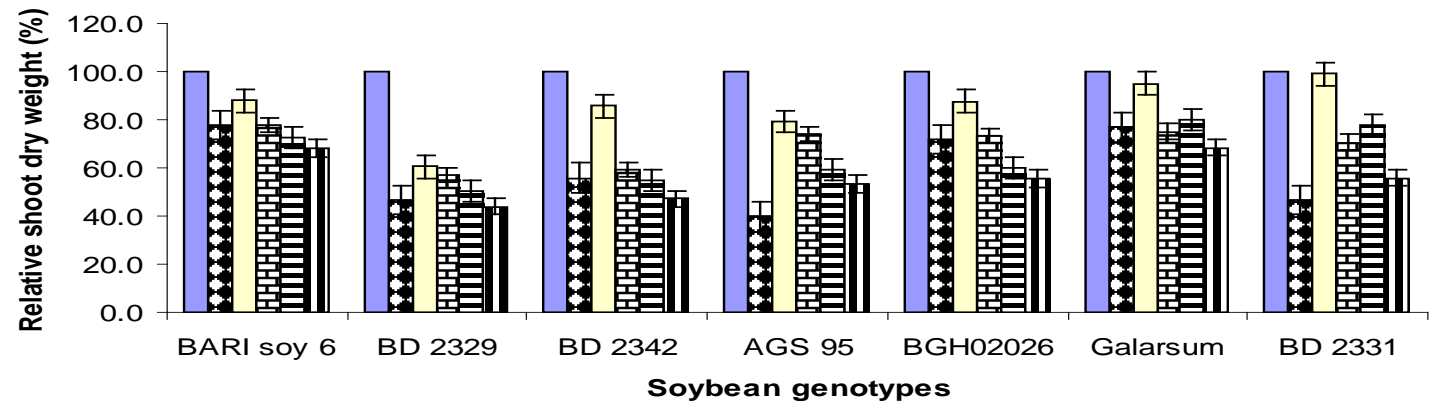

Here, Cont $=$ Control, WS $=$ Water stress, $\mathrm{mM}=\mathrm{NaCl}$ concentration .

Fig. 4. Relative shoot dry weight of soybean genotypes as affected by salinity and water stress, and their combination at $42 \mathrm{DAE}$

Wang et al. (2011) also reported that total biomass, shoot biomass, leaf biomass decreased significantly in saltcedar (Tamarix chinensis) seedlings due to water scarcity under salt and water stress condition. Under only water stress, when soil dries up, the matric potential decreases, therefore increases the resistance of water flow to the roots in a non-linear fashion (Homaee et al., 2002). Application of salt water increases in soil salinity. At given salt water content, the soil water potential reduces but does not reduce water flow to the roots. Root cortical cells can osmotic ally adjust to some extent allowing water to readily move into the root. Therefore, shoot dry weight of soybean was affected more in combined salt and water stress conditions than only in salt stress conditions. The finding is also in agreement with the findings of Meiri (1984) that the matric potential preferentially affected the shoot growth of bean more than did the osmotic potential. 
Genotypic Differences in Soybean Under NACL Salinity and Water Stress

Under salt stress condition, cell expansion is reduced due to low turgor, beside these excess sodium ion damages cell membrane and organelles, resulting in plant growth reduction. The reduction in shoot dry weight due to salinity was reported by Karim et al. (1993) in triticale, Khan et al. (1997) in rice, Aziz et al. (2005) in mungbean, Waheed et al. (2006) in pigeonpea, Jamil et al. (2007) in sugarbeet, Sultana et al. (2009) in mungbean, Chookhampaeng (2011) in pepper plant and Mannan et al. (2012) in soybean.

\section{Root dry weight}

Root dry weight of soybean genotypes decreased under water stress, salt stress and, combined salt and water stress condition (Fig. 5). Under water stress, the highest root dry weight $(0.30 \mathrm{~g})$ was recorded in BGH02026 and the lowest $(0.10 \mathrm{~g})$ in BD 2342. Root dry weight affected more in combined salt and water stress than only in salt stress in both the salinity levels (50 and $100 \mathrm{mM} \mathrm{NaCl}$ ). At higher level of salinity, the highest root dry weight (0.31 g)was recorded in both BD 2342 and BD 2331, and the lowest in BGH02026 (0.21 g). At higher level of salinity combined with water stress condition, the highest root dry weight (0.24 g) was recorded in both BD 2342 and AGS 95 genotypes, and the lowest in BD 2331(0.19 g). The relative root dry weight reduced in water stress, salt stress and, combined salt and water stress conditions (Fig. 6). The relative root dry weight was reduced more in combined salt and water stress conditions than only salt stress in both the salinity levels (50 and $100 \mathrm{mM} \mathrm{NaCl}$ ). At higher level of salt stress condition, the highest relative root dry weight recorded in Galarsum (88.4\%) which was followed by BD 2331 (74.6 \%) and the lowest recorded in BD 2329 (49.4\%). At higher level of salt combined with water stress condition, the highest root dry weight also recorded in Galarsum (69.8\%), which was followed by BGH02026 (61.1\%) and the lowest recorded in BD 2329 (42.4 \%).

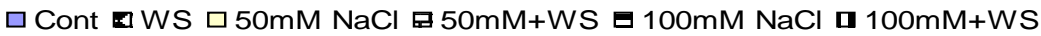

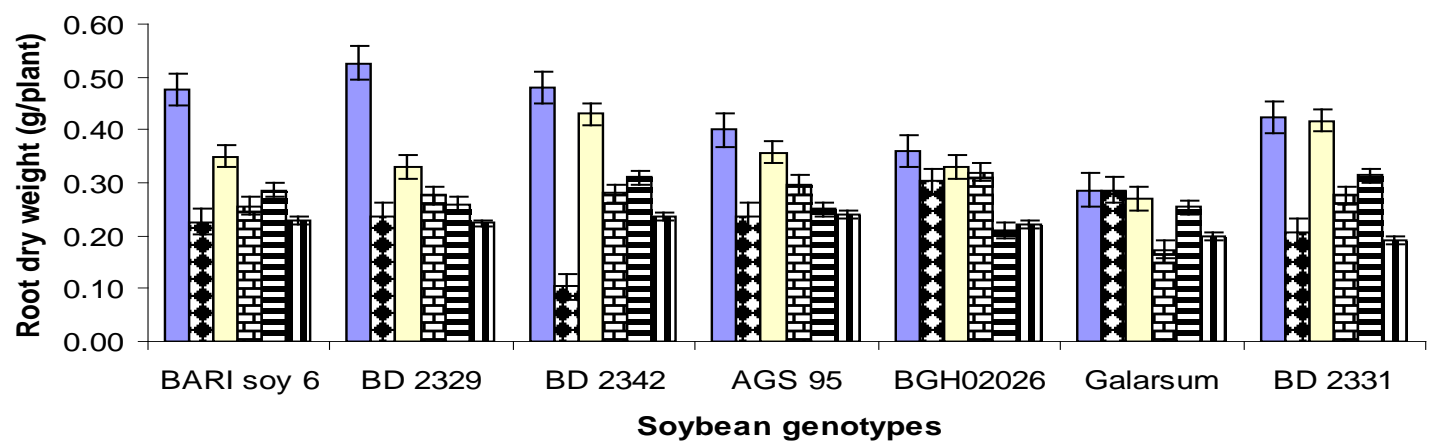

Here, Cont $=$ Control, WS $=$ Water stress, $\mathrm{mM}=\mathrm{NaCl}$ concentration.

Fig. 5. Root dry weight of soybean genotypes as affected by salinity and water stress, and their combination at $42 \mathrm{DAE}$

$\square$ Cont DWS $\square 50 \mathrm{mM} \mathrm{NaCl}$ 田50mM+WS a 100mM NaCl $\mathbf{0} 100 \mathrm{mM}+\mathrm{WS}$

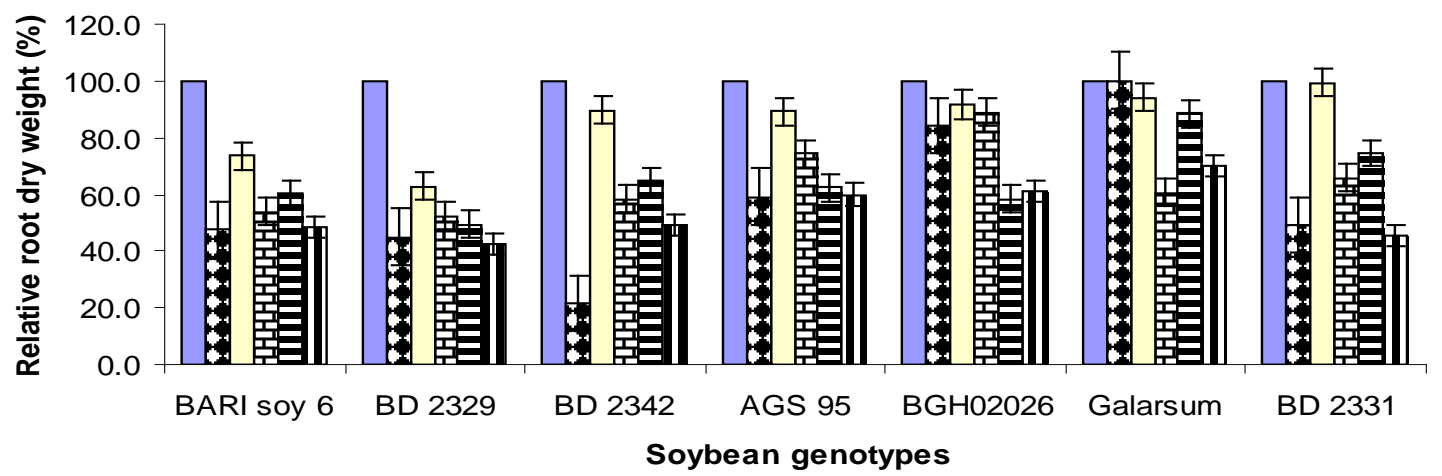


Khan et al.

Here, Cont $=$ Control, WS $=$ Water stress, $\mathrm{mM}=\mathrm{NaCl}$ concentration .

Fig. 6. Relative root dry weight of soybean genotypes as affected by salinity and water stress, and their combination at $42 \mathrm{DAE}$

Under salt and water stress condition, cell expansion is reduced due to low turgor, beside these excess sodium ion damages cell membrane and organelles, resulting in reduction of root growth. Wang et al (2011) reported that root biomass decreased significantly in tamarisk seedlings due to water severity under salt and water stress condition. Decreased in radical dry weight of mungbean under salinity and water stress was also reported by Padder et al. (2012). The reduction in root dry weight due to salinity were reported by Aziz et al. (2005); Sultana et al. (2009) in mungbean, Waheed et al. (2006) in pigeonpea, Jamil et al. (2007) in sugarbeet and Chookhampaeng (2011) in pepper plant.

\section{Dry matter distribution}

Dry matter distribution in different plant parts of soybean genotypes as affected by water stress, salt stress and, combined salt and water stress condition is presented in Fig. 7. All plant parts were reduced by stresses. Under water stress, the highest stem in BARI Soybean 6 (0.77 g), petiole $(0.25 \mathrm{~g})$ and leaves $(0.95 \mathrm{~g})$ in BD 2342 were recorded while the lowest stem $(0.36 \mathrm{~g})$, petiole $(0.14 \mathrm{~g})$ and leaves $(0.53 \mathrm{~g})$ were recorded in BD 2331. All plant parts reduced more in all genotypes in the combined salt and water stress than only in the salt stress in both the salinity levels $(50 \mathrm{mM}$ and $100 \mathrm{mM} \mathrm{NaCl})$. But the reduction was more in leaves than stem and petiole. At higher salinity, the highest leaves dry weight recorded in BD 2342 (0.93 g), which was followed by BD 2329 (0.92 g) and the lowest recorded in BGH02026 (0.71 g). But at higher level of salinity combined with water stress condition, the highest leaves dry weight recorded in BD 2329 (0.81 g) and the lowest (0.59 g) in BGH 02026.

Under water stress condition, cell expansion of leaf is reduced due to low turgor, which is controlled by the processes related to cellular water uptake and cell wall extension (Cramer and Bowman, 1993). Therefore, leaf area was decreased resulted in decreased leaves dry weight under salt and water stress condition. Long term exposure to salinity lead to premature leaf senescence; and thus reduced the photosynthetic area (Cramer et al., 1991) in soybean plants. The highest reduction of leaf dry weight in the genotype BGH02026 at $100 \mathrm{mM} \mathrm{NaCl}$ salinity might be due to high salt load in the leaf. The salt that exceeds the capacity of compartmentation in the cell vacuoles of leaf causing salt to build up in the cytoplasm to toxic levels (Munns, 2002; Munns et al., 2006). The reduction in leaf dry weight due to salinity was reported by Karim et al. (1993) in triticale, Khan et al. (1997) in rice, Aziz et al. (2005) in mungbean and Mannan et al. (2013) in soybean.






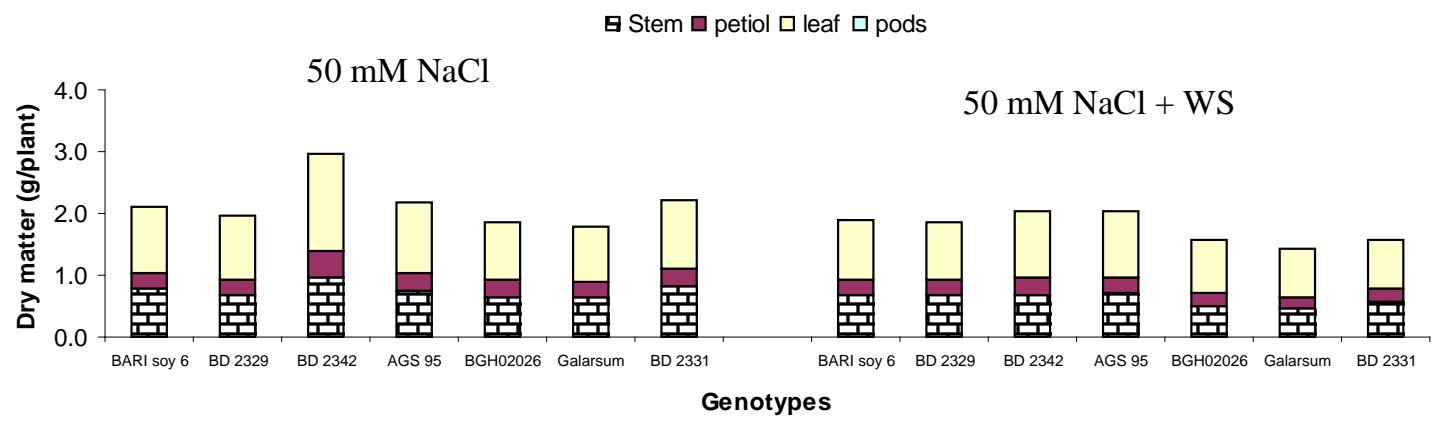

回 Stem $\square$ petiol $\square$ leaf $\square$ pods

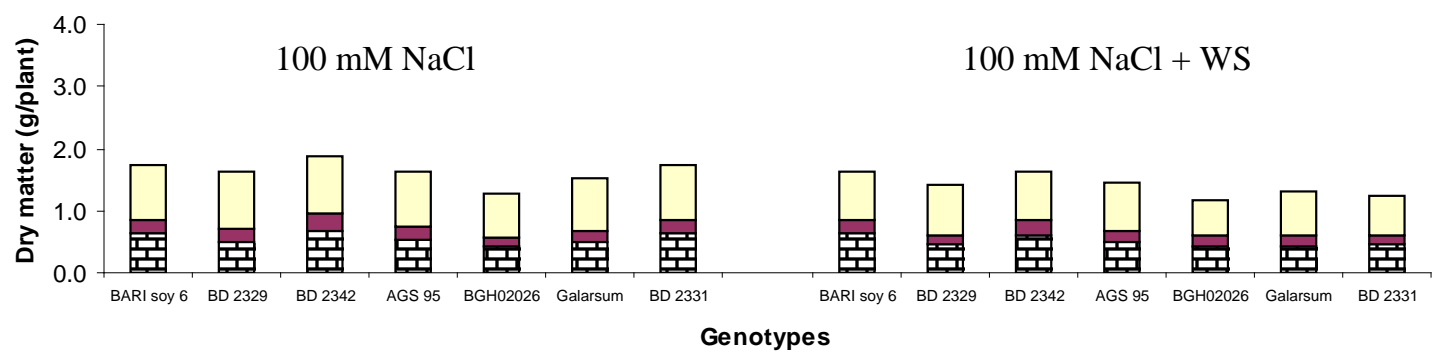

Here, Cont $=$ Control, WS $=$ Water stress, $\mathrm{mM}=\mathrm{NaCl}$ concentration

Fig. 7. Dry matter accumulation in different plant parts of soybean genotypes as affected by salinity and water stress, and their combination at $42 \mathrm{DAE}$

\section{Sodium accumulation}

Sodium (Na) uptake in leaf tissue (\%) of soybean genotypes was significantly affected by water stress, salt stress and, combined salt and water stress condition (Table 1). The accumulation of Na was lower in leaves of all the genotypes under water stress than control. Significantly the lowest Na content was found in BD 2329 (0.072 \%), which was identical with BARI Soybean $6(0.091 \%)$ in only water stress treatment. The accumulation of Na was more in the salt stress than in the combined salt and water stress conditions in both the salinity levels (50 and $100 \mathrm{mM} \mathrm{NaCl}$ ). Results reveal that concentration of $\mathrm{Na}$ increased with increasing salinity levels. Genotypic differences were also observed in Na accumulation. At higher level of salt stress (100 mM NaCl), Galarsum (0.223\%) accumulated significantly the lowest concentration of $\mathrm{Na}$, which was identical by the accumulation of BD $2331(0.226 \%)$ and the highest was accumulated by BGH 02026 (0.495\%). At higher level of salinity combined with water stress condition, Galarsum $(0.173 \%)$ was also accumulated lower amounts of $\mathrm{Na}$ which was at par with the accumulation of BD $2331(0.182 \%)$ and the highest in AGS 95 (0.330\%).The results are in agreement with the earlier reports that tolerant genotypes accumulate lower amount of Na than the salt sensitive ones (Karim et al., 1992; Khan et al., 1997; Ahmadi et al., 2009; Mannan et al., 2013). Kao et al. (2006) also reported that differences among soybean species in leaf accumulation of $\mathrm{Na}^{+}$might be responsible for the differential sensitivity to $\mathrm{NaCl}$ treatments. Plant responses to salt and water stress have much in common phenomenon. Salinity leads to many metabolic changes identical to those caused by water stress, and there are still salt-specific effects. Accumulation of $\mathrm{Na}^{+}$in leaves results in necrosis and premature leaf senescence (Munns, 2002). 
Khan et al.

Table 1. Sodium (Na) uptake in leaf tissue (\%) of soybean genotypes as affected by salinity and water stress

\begin{tabular}{l|c|c|c|c|c|c}
\hline Genotypes & Control & $\begin{array}{c}\text { Water } \\
\text { stress (WS) }\end{array}$ & $\begin{array}{c}50 \mathrm{mM} \\
\mathrm{NaCl}\end{array}$ & $\begin{array}{c}50 \mathrm{mM} \\
\mathrm{NaCl}+\mathrm{WS}\end{array}$ & $\begin{array}{c}100 \mathrm{mM} \\
\mathrm{NaCl}\end{array}$ & $\begin{array}{c}100 \mathrm{mM} \\
\mathrm{NaCl}+\mathrm{WS}\end{array}$ \\
\hline BARI Soy-6 & 0.136 & 0.091 & 0.319 & 0.179 & 0.390 & 0.226 \\
BD 2329 & 0.083 & 0.072 & 0.275 & 0.195 & 0.330 & 0.198 \\
BD 2342 & 0.143 & 0.121 & 0.283 & 0.217 & 0.358 & 0.303 \\
AGS 95 & 0.162 & 0.094 & 0.286 & 0.239 & 0.385 & 0.330 \\
BGH 02026 & 0.165 & 0.143 & 0.413 & 0.253 & 0.495 & 0.292 \\
Galarsum & 0.132 & 0.105 & 0.160 & 0.138 & 0.223 & 0.173 \\
BD 2331 & 0.105 & 0.094 & 0.162 & 0.143 & 0.226 & 0.181 \\
\hline LSD $(0.01)$ & \multicolumn{7}{c}{0.022} \\
CV (\%) & \multicolumn{7}{|l}{4.98} \\
\hline
\end{tabular}

\section{Potassium accumulation}

Accumulation of potassium (K) in leaf tissue (\%) of soybean genotypes was also affected by water stress, salt stress and, combined salt and water stress condition (Table 2). The accumulation of $\mathrm{K}$ was higher in leaves under water stress than control. Under only water stress treatment, significantly the highest $\mathrm{K}$ content was found in BD 2331 (2.52 \%), which was identical by the accumulation of BD 2342 (2.42\%) and the lowest in AGS 95 (1.96\%). The accumulation of $\mathrm{K}$ was more in the combined salt and water stress than in the salt stress conditions in both the salinity levels (50 and $100 \mathrm{mM} \mathrm{NaCl})$ in all the genotypes, except BARI Soybean 6 and BGH 02026. The accumulation of K decreased with increasing salinity levels. At higher level of salt stress $(100 \mathrm{mM} \mathrm{NaCl})$, Galarsum $(1.75 \%)$ accumulated significantly the highest amounts of $\mathrm{K}$ which was identical by the accumulation of AGS 95 (1.70\%), BD 2331 (1.70 \%) and BARI Soybean 6 (1.65 \%). The least amount of K was accumulated by BD 2342 (1.55 $\%)$ at this level of salinity. At higher level of salinity combined with water stress condition, Galarsum $(1.80 \%)$ also accumulated significantly the highest amounts of $\mathrm{K}$, which was identical by the accumulation of BD 2331 (1.75 \%), AGS 95 (1.75 \%) and BD 2329 (1.70 \%), while BGH 02026 (1.34 $\%)$ accumulated the least.Under water stress as well as under salt stress conditions, $\mathrm{K}$ plays an important role in osmoregulation, and stress tolerant genotypes accumulate higher amounts of $\mathrm{K}$ than susceptible ones (Blum, 1988; Qadar, 1988). Here, soybean genotype Galarsum accumulated higher amount of K in leaves than others under the salt and water stress conditions. A greater degree of salt tolerance in plants was found to be associated with a more efficient system for selective uptake of K over Na (Neill et al., 2002). The selective uptake of $\mathrm{K}$ in contrast to $\mathrm{Na}$ is considered as one of the important physiological mechanisms contributing to salt tolerance in many plant species (Poustini and Siosemardeh, 2004). There was a negative relationship between $\mathrm{Na}$ and $\mathrm{K}$ concentration in leaves. Similar results had been observed by Khan et al. (1997) and Goudarzi and Pakniyat (2008).

Table 2. Potassium (K) uptake in leaf tissue (\%) of soybean genotypes as affected by salinity and water stress

\begin{tabular}{l|c|c|c|c|c|c}
\hline Genotypes & Control & $\begin{array}{c}\text { Water } \\
\text { stress (WS) }\end{array}$ & $\begin{array}{c}50 \mathrm{mM} \\
\mathrm{NaCl}\end{array}$ & $\begin{array}{c}50 \mathrm{mM} \\
\mathrm{NaCl}+\mathrm{WS}\end{array}$ & $\begin{array}{c}100 \mathrm{mM} \\
\mathrm{NaCl}\end{array}$ & $\begin{array}{c}100 \mathrm{mM} \\
\mathrm{NaCl}+\mathrm{WS}\end{array}$ \\
\hline BARI Soy-6 & 1.96 & 2.16 & 2.06 & 1.56 & 1.65 & 1.44 \\
BD 2329 & 2.06 & 2.37 & 1.96 & 2.11 & 1.56 & 1.70 \\
BD 2342 & 2.37 & 2.42 & 1.75 & 1.96 & 1.55 & 1.65 \\
AGS 95 & 1.75 & 1.96 & 1.80 & 1.85 & 1.70 & 1.75 \\
BGH 02026 & 2.16 & 2.22 & 2.01 & 2.06 & 1.56 & 1.34 \\
Galarsum & 1.85 & 2.16 & 1.96 & 2.06 & 1.75 & 1.80 \\
BD 2331 & 1.70 & 2.52 & 2.16 & 2.16 & 1.70 & 1.75 \\
\hline
\end{tabular}


Genotypic Differences in Soybean Under NACL Salinity and Water Stress

\begin{tabular}{ll}
\hline LSD $_{(0.01)}$ & 0.15 \\
$\mathrm{CV}(\%)$ & 3.74 \\
\hline
\end{tabular}

\section{Conclusion}

The results of this study indicated that all the growth characters of the soybean genotypes sharply decreased when plants were exposed to water stress, salt stress and, combined salt and water stress conditions. Variation in salt and water stress tolerance of soybean genotypes was obvious. Among the genotypes, reduction in dry matter production was least in Galarsum and BD 2331 in both salt and, combined salt and water stress conditions. These genotypes also accumulated lower amount of $\mathrm{Na}$ and higher amount of $\mathrm{K}$ in leaf tissues under the salt stress and, the combined salt and water stress environments as compared to others.

\section{References}

Abdulrahman, F. S. and G. S. Williams III. 1981. Temperature and salinity regulation of growth and gas exchange of Salicornia fruticosa (L.) L. Oecologia. 48: 346-352.

Ahmadi, A., Y. Emam and M. Pessarakli. 2009. Response of various cultivars of wheat and maize to salinity stress. J. Food Agri. Environ. 7: 123-128.

Aziz, M. A., M. A. Karim, M. A. Hamid, Q. A. Khalique and M. Hossain. 2005. Salt tolerance in mungbean: Growth and yield response of some selected mungbean genotypes to $\mathrm{NaCl}$ salinity. Bangladesh $\mathrm{J}$. Agric. Res. 30: 529-535.

Blum, A. 1988. Salinity resistance. In: Plant Breeding for Stress Environments. CRC Press, Florida. pp. 163179.

Chookhampaeng, S. 2011. The effect of salt stress on growth, chlorophyll content proline content and antioxidative enzymes of Pepper (Capsicum Annuum L.) seedling. European J. Sci. Res. 49(1): 103109.

Cramer G. R. 1991. Kinetics of maize leaf elongation. II. Responses of a sodium excluding cultivar and a Na including cultivar to varying $\mathrm{Na} / \mathrm{Ca}$ salinity. J. Expt. Bot. 43: 857-864.

Cramer G. R. and D. C. Bowman. 1993. Cell elongation control under stress conditions. In: Handbook of Plant and Crop Stress, M. Pessarakli (Ed.). Marcel Dekker, New York, pp.303-319.

Ghassemi-Golezani, K. M. Taifeh-Noori, Sh. Oustan and M. Moghaddam. 2009. Response of soybean cultivars to salinity stress. J. Food, Agric.Environ.7(2): 401-404.

Gill, K. S. 1990. Effect of saline irrigation at various growth stages on growth, yield attributes and ionic accumulation pattern in green gram (Phaseolus radiatus). Indian J. Agric. Sci. 54: 210-212.

Gingrich, J. R. and M. B. Russell. 1957. A comparison of effects of soil moisture tension and osmotic stress on root growth. Soil Sci. 84: 185-194.

Goudarzi, M. and H. Pakniyat. 2008. Evaluation of wheat cultivars under salinity stress based on some agronomic and physiological traits. J. Agri. Soc. Sci.1: 35-38.

Greenway, H. and R. Munns. 1980. Mechanisms of salt tolerance in nonhalophytes. Ann. Rev.Plant Physiol. 31: $149-190$

Hayward, H. E. and W. B. Spurr. 1943. Effects of osmotic concentration of substrate on the entry of water into corn roots. Bot. Gaz. 105: 152-164.

Homaee, M., R. A. Feddes and C. Dirksen. 2002. A macroscopic water extraction model for nonuniform transient salinity and water stress. Soil Sci. Soc. Am. J., 66: 1764-1772. 
Khan et al.

Jamil, M., S. Rehman and E. S. Rha. 2007. Salinity effect on plant growth, PSII photochemistry and chlorophyll content in sugar beet (Beta vulgaris L.) and cabbage (Brassica oleraces capitata L.). Pak. J. Bot., 39(3): 753-760.

Kao, W., T. T. Tyng, C. T. Hung and N. S. Chen. 2006. Response of three Glycine species to salt stress. Environ. Expt. Bot. 56: 120-125.

Karim, M. A., E. Nawata and S. Shigenaga. 1992. Dry matter production and distribution of mineral ions in different parts of the plant in hexaploid triticale. Japanese J.Crop Sci. 61: 439-446.

Karim, M. A., E. Nawata and S. Shigenaga. 1993. Effects of salinity and water stress on growth, yield and physiological characteristics in hexaploid triticale. Japanese J.Trop. Agr. 37(1): 46-52.

Khan, M. S. A., A. Hamid, A. B. M. Salahuddin, A. Quasem and M. A. Karim. 1997. Effect of sodium chloride on growth, photosunthesis and mineral ions accumulation of different types of rice (Oryza sativa L.). J. Agron.Crop Sci. 179: 149-161.

Khan, M. S. A. 2013. Evaluation of soybean genotypes in relation to yield performance, salinity and drought tolerance. Ph.D. Dissertation. Department of Agronomy. Bangabandhu Sheikh Mujibur Rahman Agricultural University. Salna. Gazipur-1703.

Maas, E. V. and G. J. Hoffman. 1977. Crop salt tolerance- current assessment. J. Irrig. Drain. Div. ASCE. 103 (2): $115-134$.

Maas, E.V. and Poss, J.V. 1989. Salt sensitivity of cowpea at various growth stages. Irrig. Sci. 10: 313-320.

Mannan, M. A., M. A. Karim, M. M. Haque, Q. A. Khaliq, H. Higuchi and E. Nawata. 2012. Response of soybean to salinity: I. Genotypic variations in salt tolerance at the vegetative stage. Trop. Agr. Develop. 56(4): 117-122.

Mannan, M. A., M. A. Karim, M. M. Haque, Q. A. Khaliq, H. Higuchi and E. Nawata. 2013. Response of soybean to salinity: II. Growth and yield of some selected genotypes. Trop. Agr. Develop. 57(1): 3140.

Mannan, M. A., M. A. Karim, M. M. Haque, Q. A. Khaliq, H. Higuchi and E. Nawata. 2013. Response of soybean to salinity: III. Water status and accumulation of mineral ions. Trop. Agr. Develop. 57(1): 41-48.

Meiri, A. 1984. Plant response to salinity: Experimental methodology and application to the field. p. 284-297. In I. Shainberg and J. Shalhevet (eds.) Soil Salinity Under rrigation. Springer Verlag, New York.

Munns R., R. A. James and A. Läuchli. 2006. Approaches to increasing the salt tolerance of wheat and other cereals. J. Expt. Bot. 57: 1025-1043.

Munns, R. 2002. Comparative physiology of salt and water stress. Plant Cell Environ. 25: 239-250.

Munns, R., R.A. Hare, R. A. James and G. J. Rebetzke. 2000. Genetic variation for improving the salt resistance of durum wheat. Aust. J. Agric. Res., 51: 69-74.

Neill, S., R. Desikan, and J. Hancock. 2002. Hydrogen peroxide signalling. Curr. Opin. Plant Biol. 5: 388-395.

Ozturk, A., A. Unlukara, A. Ipek and B. Gurbuz. 2004. Effects of salt stress and water deficit on plant growth and essential oil content of lemon balm (Melissa officinalis). Pak. J. Bot., 36(4): 787-792.

Padder, M. B, R. Yadav and R. M. Agarwal. 2012. Effect of salinity and water stress in mungbean (Vigna radiata) L. Wilczek var. Hum_1. Plant Sci. Feed 2(9): 130-134.

Poustini, K. and A. Siosemardeh. 2004. Ion distribution in wheat cultivars in response to salinity stress. Field Crops Res. 85: 125- 33.

Qadar, A. 1988. Potassium status of the rice shoot as an index for salt tolerance. Ind. J. Plant Physiol. 31: 388393.

Raptan, P. K., A. Hamid, Q. A. Khaliq, A. R. M. Solaiman, J. U. Ahmed and M. A. Karim. 2001. Salinity tolerance of blackgram and mungbean: I. Dry matter accumulation in different plant parts. Korean J. Crop Sci. 46: 380-386. 
Genotypic Differences in Soybean Under NACL Salinity and Water Stress

Sari, A. O. and A. Ceylan. 2002. Yield characteristics and essential oil composition of lemon balm (Melissa officinalis L.) grown in the Aegean Region in Turkey. Tr. J. Agric. Forestry, 26(4): 217-224.

Sultana, M. S., M. A. Karim, F. Hossain, M. A. Halim and M. T. Hossain. 2009. Effect of salinity on growth and yield of two mungbean varieties differing in salinity tolerance. Bangladesh J. Life Sci. 21(2): 4752.

Tester, M. and R. Davenport. 2003. Na+ resistance and Na+ transport in higher plants. Ann. Bot. 91: 1-25.

Waheed, A., I. A. Hafiz, G. Qadir, G. Murtaza, T. Mahmood and M. Ashraf. 2006. Effect of salinity on germination, growth, yield, ionic balance and solute composition of pigeon pea (Cajanus cajan L. MillSP). Pakistan J. Bot. 38(4): 1103-1117.

Wang, Wei, R. Wang, Y. Yuan, N. Du and W. Guo. 2011. Effects of salt and water stress on plant biomass and photosynthetic characteristics of Tamarisk (Tamarix chinensis Lour.) seedlings. Afr. J. Biotechnol. 10(78): 17981-89. 